\title{
REDE DE SIGNIFICAÇÕES: PERSPECTIVA PARA ANÁLISE DA INSERÇÃO DE BEBESS NA CRECHE
}

\author{
KATIA DE SOUZA AMORIM \\ TELMA VITORIA \\ MARIA CLOTILDE ROSSETTI-FERREIRA \\ Centro de Investigações sobre Desenvolvimento Humano e Educação Infantil - CINDEDI
}

RESUMO

\begin{abstract}
A inserção de bebês em creche envolve familiares, crianças e educadoras em um complexo processo de integração, particularmente em nossa cultura, em que a educação coletiva de bebês é fenômeno recente. As representações sociais e a literatura científica reforçam a noção de que idealmente bebês devem ser cuidados em casa, pela mãe. Assim, freqüentemente, essa se sente culpada por ter que compartilhar os cuidados do(s) filho(s). O período inicial do bebê em uma creche, portanto, implica a emergência de novos significados que são atribuídos e assumidos, confrontados e negociados nas interações estabelecidas pelos participantes. Uma perspectiva teórico-metodológica foi desenvolvida para analisar esse processo, baseado em um projeto de pesquisa que acompanhou a inserção de 26 bebês (5- 18 meses de idade) em uma creche. Registrou-se a situação a partir de gravações em vídeo, fichas de observação e entrevistas. A perspectiva referida destaca três personagens centrais: mãe, criança e educadora, em seus mútuos relacionamentos, os quais criam vários campos interconectados. O campo mãe-criança está inserido, principalmente, no cenário da família. Os outros dois, educadora-criança e mãe-educadora, no cenário da creche. Ambos os cenários estão impregnados por uma matriz socioistórica ampla, criada por complexo sistema cultural, econômico e político. Os vários elementos formam uma rede de significações semióticas, que continuamente se transforma e estrutura/desestrutura o desenvolvimento humano.
\end{abstract}

BEBEES-CRECHES-DESENVOLVIMENTOINFANTIL - FAMÍLIAS-MÃES

\section{ABSTRACT}

THEINSERTION OFBABIESINTOADAY CARECENTERANALYSED THROUGHANETWORKOFMEANINGS. The insertion of babies in a day care involves family members, child and caregivers in a complex integration process, as in our culture, collective education is a recent phenomenon. Social representations and scientific literature reinforce the notion that, by nature, babies require personal care at home, by their own mother. Consequently, she often feels guilty for leaving her baby in an institution. The baby's first period in a day care thus implies the emergence and creation of new meanings which are attributed to, assumed by, confronted to and negotiated in the interactions established by all participants. A model was developed to analyse this process based on a research project on the insertion of 26 infants ( 5 to 18 months old) into a day care. Video recordings, observational reports, as well as interviews with mothers, caregivers and technicians were made during the babies' first year at an university day care centre. The model focus on three main personages: mother, child and caregiver and on their mutual relationships which create three interconnected fields. The mother-child field is inserted in a larger network, the family scenery. The other two, caregiver-child and mother-caregiver fields are located in the day-care scenery. Both scenarios are impregnated by a wider social-historical matrix created in complex cultural, economic and political systems. The various elements are interconnected in a semiotic network of meanings, which continuously transforms and structures human development, allowing varied paths of behavior for each individual.

Agradecemos os auxílios recebidos da FAPESP e do CNPq que possibilitaram o desenvolvimento deste trabalho. 


\section{INTRODUÇÃO}

Equipamentos de cuidado e educação coletiva (como creche, "escolinha", berçário etc.) vêm atendendo a uma demanda crescente de crianças, cada vez mais novas, oriundas de famílias de diferentes camadas da população. Esses equipamentos surgem como conseqüência de transformações socioeconômicas e culturais, as quais têm alterado os modos de vida e de relacionamento entre os indivíduos, e o exercício de suas funções, em especial daquelas realizadas pelas mulheres (Durham, 1983; Vaitsman, 1994).

Especialmente nas últimas três décadas, as mulheres, independentemente de sua origem social, têm passado a trabalhar fora de casa, motivadas seja pela necessidade de contribuir para a sobrevivência da família, seja pelo desejo de realização profissional. Como decorrência, têm buscado soluções que as apóiem e as auxiliem nos cuidados dos filhos, soluções essas nem sempre efetivas dentro do próprio contexto familiar. Tal dificuldade deve-se, em grande parte, ao maior isolamento das famílias, fruto das modificações nas condições sociodemográficas, as quais envolvem a migração de populações rurais para centros urbanos industrializados, a diminuição no número de elementos na família, a menor rede de apoio familiar e de vizinhança, além de um distanciamento físico e psicológico entre os membros da família extensa, como irmãos, tios, avós... (Oliveira, Rossetti-Ferreira, 1986).

Além disso, verifica-se que, na atual sociedade ocidental capitalista, apesar de existir um predomínio da estruturação familiar baseada no modelo "nuclear" (constituída, basicamente, por pai, mãe e filhos), novos padrões familiares têm emergido. Observa-se, assim, uma crescente coexistência de diferentes padrões de relações afetivo-sexuais, com a presença de mães e/ou pais solteiros ou descasados, famílias agregadas com filhos de diferentes casamentos, famílias com filhos adotivos e famílias de homossexuais, dentre outras.

Os novos papéis, além das novas estruturas, relacionamentos e formas de relações familiares, têm promovido o compartilhamento dos cuidados dos filhos com outros membros da família extensa e com empregadas no próprio ambiente doméstico. Têm levado também as famílias a uma crescente procura por escolinhas, berçários, creches etc. (Oliveira, Rossetti-Ferreira, 1986).

Nesse contexto, algumas concepções a respeito do exercício da maternidade e da educação de bebês em ambientes coletivos mostram-se especialmente relevantes e, ao mesmo tempo, conflitantes.

Em nossa sociedade, prevalece a idéia de que o cuidado ideal e capaz de garantir condições adequadas ao desenvolvimento do bebê é aquele provido pela mãe, no ambiente doméstico. Assume-se, assim, que o modelo de educação de crianças pequenas dentro da família nuclear é "natural", isto é, requerido por características próprias do ser humano. Contextos de desenvolvimento diversos, como o cuidado coletivo de crianças em creche, representariam um "mal necessário" (Vieira, 1988), constituindo um risco ao 
desenvolvimento sadio da criança, sendo aceitos apenas naqueles casos em que a mãe ou a família não têm condições de criar o filho em casa.

Essa visão vem sendo contestada, especialmente a partir de estudos que mostram como essa perspectiva é influenciada por práticas, concepções e valores sociais, constituídos histórica e ideologicamente. $\bigcirc$ exercício da maternidade, nos moldes como conhecemos hoje, segundo autores como Ariès (1978), Badinter (1985) e Poster (1979), é relativamente recente na história da humanidade e suas características estão intimamente associadas às condições socioeconômicas e culturais, resultantes de transformações que ocorreram nas várias sociedades.

Essas contradições e ambigüidades na forma de encarar o lugar da mulher/mãe na sociedade e a educação coletiva de crianças, nos primeiros anos de vida, estão também presentes na forma como o Estado concebe sua responsabilidade pela educação da criança pequena. Por um lado, temos países, como os Estados Unidos e a Inglaterra, que, em geral, atribuem essa função quase exclusivamente à família, assumindo esses cuidados apenas com a conotação de "mal necessário". Já outros, como os Escandinavos, a França, a Austrália, Israel, assim como alguns países ex-socialistas, como a Hungria, propõem que essa responsabilidade deva ser compartilhada entre as famílias e o Estado, com a promoção de cuidados e educação em ambientes do tipo creche. No Brasil, tem havido, nas últimas décadas, importantes transformações, fruto da luta de vários profissionais, associações e, inclusive, das próprias famílias, ao pleitearem do Estado e de organizações não governamentais - ONGs - uma educação de qualidade para seus filhos. Mediante essas reivindicações, conseguiu-se que, na Constituição Nacional de 1988, o atendimento às crianças de 0 a 6 anos fosse incluído no capítulo da Educação, sendo definido como um direito da criança, um dever do Estado e uma opção da família, tirando-lhe assim a conotação meramente assistencial, típica dos momentos anteriores.

Mais recentemente, com a promulgação da nova Lei de Diretrizes e Bases da Educação (DO de 23/I2/96) e o novo Plano Nacional da Educação, em elaboração, observamse avanços na legislação sobre educação infantil, na qual é contemplado o atendimento de crianças de 0 a 3 anos (em creches) e de 4 a 6 anos (em pré-escolas). Esses avanços podem ser especialmente apontados no que diz respeito ao registro, ao recenseamento e ao controle das instituições de educação infantil; à proposta de eixos norteadores (como as Diretrizes e o Referencial Curricular Nacional); à maior participação das famílias nos assuntos da escola; e à maior autonomia das escolas na elaboração de programas pedagógicos. Entretanto, alguns aspectos fundamentais para a promoção de qualidade desses serviços não ficaram garantidos, como por exemplo, a previsão de financiamento para os mesmos e a garantia de qualificação do profissional de creche.

É interessante notar como essas formas de organização social e política se apóiam em ideologias específicas que, freqüentemente, norteiam as pesquisas científicas desenvolvidas nos vários países. Assim, nas publicações americanas e inglesas, predominam as 
pesquisas e discussões sobre os "efeitos" da educação na criança pequena, particularmente em seus dois primeiros anos de vida, em ambientes diversos do familiar. Os pesquisadores partem da noção de que o bebê humano requer o cuidado em casa pela mãe, não sendo adequados outros contextos para ele se desenvolver satisfatoriamente. Fundamentados na Teoria do Apego (Bowlby, 1969), tais estudos usam em geral o paradigma da "Situação Estranha", de Ainsworth et al. (1978), a fim de verificar, nas relações de apego mãecriança, a existência de alterações provocadas pela freqüência precoce à creche (Belsky, 1990; Sroufe, 1990). Além disso, estudos longitudinais procuram analisar eventuais alterações no comportamento social da criança. Os resultados dessas pesquisas têm-se mostrado contraditórios e não conclusivos (Fox, Fein, 1990). E o recente estudo coordenado pelo NICHD (1997), nos Estados Unidos, indica que os prejuízos não podem ser atribuídos exclusivamente aos cuidados/educação em ambientes coletivos, mesmo no caso de crianças que viveram essa experiência nos primeiros anos de vida. Os pesquisadores reconhecem que tanto a qualidade do apego como o comportamento social da criança estão intimamente relacionados à qualidade das relações estabelecidas e do atendimento oferecido, seja em casa ou na instituição.

Por outro lado, os países escandinavos, a Austrália, a França, a Itália, e alguns centros na Itália e no Brasil, reconhecendo a diversidade de ambientes, de necessidades e de formas de relações que as crianças pequenas atualmente vivenciam em seu cotidiano, preocupam-se mais em investigar como promover um atendimento de qualidade em creches, nos seus vários aspectos (CRESAS, 1991; Fiorani, Musatti, 1986; Mantovani, Terzi, 1987; Pramling, Lindahl, 1992; Oliveira, Rossetti-Ferreira, 1986 e 1993; Vitória, Rossetti-Ferreira, 1993; Rossetti-Ferreira et al., 1998).

Entretanto, no Brasil, assim como em diversos países, a imagem da creche ainda se encontra negativamente marcada por sua atuação em atividades de caráter assistencialista e filantrópico, de combate à pobreza e à mortalidade infantil, freqüentemente associadas a situações de grande miséria e desestruturação familiar. Além disso, as características básicas do atendimento oferecido naquelas condições marcam, ainda hoje, a rotina de funcionamento da maioria das creches, organizadas de modo a dar maior atenção à guarda e aos cuidados físicos da criança (Silveira et al., 1987).

Mais recentemente, a creche tem assumido outras funções sociais, tanto pelo fato de começar a atender crianças provenientes das camadas médias da população, como pela influência que tem sofrido das novas teorias das áreas da educação e psicologia (Rosemberg, 1995), como ainda pela elaboração de novas diretrizes e legislações. A creche começa, assim, a ser considerada como uma alternativa viável de cuidados, com maior aceitação, especialmente, para as crianças acima de dois ou três anos de idade. Mesmo mulheres que não trabalham fora de casa a têm procurado como espaço de socialização para suas crianças, pois acreditam que, nesses novos ambientes, seus filhos terão mais oportunidades de fazer amigos, já que, de modo geral, contam com poucos recursos no espaço doméstico 
(Oliveira, Rossetti-Ferreira, 1986). Com base nessas novas concepções, as famílias têm chegado à instituição esperando que a creche desempenhe funções de caráter mais socializante e pedagógico.

No tradicional modelo familiar de educação das camadas médias, todavia, as crianças são formadas sobretudo pelo adulto, o qual é visto não só como o promotor do desenvolvimento e do aprendizado, mas também, como o principal agente que interage com a criança. Esse fato conflita com a estrutura da creche, na qual a proporção adultocriança é mais baixa do que a que se encontra no ambiente doméstico e os parceiros mais disponíveis para a interação são outras crianças. Desse modo, os pais têm, por vezes, a impressão de falta de cuidados individuais apropriados a seus filhos, nesses ambientes.

A estrutura básica de funcionamento da creche conflita, também, com um conjunto de valores que hoje a sociedade professa e que são definidos pela busca de identidade, individualidade e intimidade (Vaitsman, 1994). Tais valores podem ser percebidos como inatingíveis em uma situação de creche, onde o espaço físico e os brinquedos são coletivos, sem a possibilidade de garantia de posse ou privacidade; onde as atividades e rotinas são compartilhadas pelas diferentes crianças e os momentos culturalmente considerados íntimos, como o banho e a amamentação, passam a ser realizados em público, devendo o decoro e a sexualidade serem reavaliados.

Há, também, uma indefinição quanto ao papel social e educacional da creche, o que resulta em influências sobre as pessoas que nela trabalham e que dela se beneficiam. Muitas creches, por exemplo, propõem-se a uma atuação como "substituta" da mãe, o que, além de ser impossível, acentua nos pais o temor de que a criança passe a gostar mais das educadoras e do novo ambiente. A educadora, por sua vez, é induzida a uma postura crítica com relação às mães e ao não-exercício pleno da maternidade por essas mães.

Esses vários elementos, associados a algumas características de ordem institucional, além da freqüente má formação do profissional de creche, tendem a conduzir os familiares que optam por esse tipo de educação para seus filhos, a uma situação de profunda ambivalência, com a emergência de fortes sentimentos de culpa e angústia, favorecendo questionamentos sobre a capacidade de a creche cuidar e educar crianças pequenas.

Seria ingênuo, portanto, tratar o dilema dessas famílias de uma forma puramente psicológica e/ou individual, ou como decorrente de uma ruptura em sistemas de comportamento programados biologicamente - como a ruptura da relação de apego.

Nesse sentido, nossa pesquisa direcionou-se para a investigação da situação de ingresso de bebês (primeiro ano de vida) na creche, procurando verificar os fatores que envolvem o bebê, a mãe e as educadoras na situação de inserção e de freqüência à creche, assim como o modo como esses fatores se articulam no desenvolvimento desse complexo processo de integração.

Esse estudo resultou na elaboração de uma nova perspectiva teórico-metodológica, a qual propõe que o processo em foco se desenvolve dentro de uma rede de significações, 
em contínua transformação. $\bigcirc$ artigo a seguir tem por objetivo apresentar essa perspectiva teórico-metodológica, ainda em construção.

\section{ALGUNS PRESSUPOSTOS TEÓRICOS}

Nossa investigação está basicamente fundamentada no referencial socioistórico, o qual tem, como principais teóricos, Wallon (1986) e Vygotski (1991; 1993).

Partindo desse referencial, entendemos que o desenvolvimento humano é um processo que se dá, do nascimento à morte, em ambientes culturalmente organizados e socialmente regulados, mediante as interações estabelecidas com parceiros, nas quais cada pessoa (adulto ou criança) desempenha um papel ativo (Valsiner, 1987).

O processo de desenvolvimento é sempre concretizado no aqui-agora das situações, nas e por meio das interações sociais, e envolve uma co-construção a partir de interações, isto é, de ações partilhadas e interdependentes, articuladas por uma coordenação de papéis. Por meio dessa, os participantes assumem, negam e/ou recriam os significados que Ihes são atribuídos, os quais são, então, integrados criativamente às suas ações, transformando-as, e às funções psicológicas que lhes dão suporte, remodelando seus propósitos e abrindo novas possibilidades de desenvolvimento (Oliveira, 1995). Nesse processo, ocorre um jogo entre a imitação dos modelos (fusão) e o confronto das necessidades, dos sentidos e das representações (diferenciação) (Wallon, 1995), numa dinâmica segmentação e unificação de fragmentos de experiências passadas, associadas às perspectivas futuras, fundidas nas situações presentes. Assim, cada pessoa negocia os significados que atribui a si mesma, ao outro e à situação como um todo e constrói a sua individualidade, constituindo-se como sujeito, no decorrer de toda a sua vida. E, ao mesmo tempo em que se transforma, transforma também o meio em que está inserida.

Os diversos meios que as pessoas freqüentam são estruturados por suas características físicas, sociais, ideológicas e simbólicas, as quais se encontram dinâmica e dialeticamente inter-relacionadas (Wallon, 1986a). Todas aquelas características são constituídas por elementos semióticos e representam elementos mediadores das relações dos homens entre si e deles com o mundo (Pino, 1995). O meio, como apresentado por Wallon (1986a), tem fundamentalmente duas funções: a de ambiente, contexto ou campo de aplicação de condutas (milieu); e a de condição, recurso, instrumento de desenvolvimento (moyen). Nesse sentido, as pessoas com quem se convive constituem seu meio social, seu espaço de experiência, tornando-se, assim, um meio (instrumento, recurso) para seu desenvolvimento.

Portanto, é por intermédio dos processos interativos que ocorrem nos diferentes contextos sociais, que são significadas e delimitadas as mais diversas características da pessoa, do parceiro, da interação e do contexto em que se encontram inseridos. Assim, por exemplo, são atribuídos significados às instituições, e dentre elas a creche. Impregnada por 
esses significados, ela passa a assumir determinadas funções e a estruturar suas atividades, práticas, rotinas e tipos de relacionamentos com as crianças, suas famílias e educadoras. Esses significados impregnam, também, os membros e suas relações na instituição família: organizam sua estrutura, atribuem papéis e promovem formas de afetividade entre seus membros; estabelecem possibilidade de identidade sexual e relações de gênero, de competência e de poder. Apontam, ainda, para concepções de infância e de desenvolvimento infantil, de papel da mulher e da mãe, de maternidade e paternidade, da mulher no mercado de trabalho e da dona de casa, dos modelos ideais de educação de filhos.

Essa organização do meio social, com os sistemas de significações e a estruturação de normas, rituais e regras de conduta, representa o que Valsiner (1987) denomina de constraints, ou "coações"'. Segundo esse autor, as coações referem-se aos limites externos (físicos ou orgânicos) e/ou cognitivos, que pertencem a um repertório coletivo compartiIhado por determinada sociedade ou grupo social. Eles são demarcados pelos parceiros e contextos, ao longo de todo o processo de socialização, canalizando e dirigindo os comportamentos, sentimentos, conhecimentos e motivações, em certas direções e não outras. Entretanto, o autor afirma que, apesar dos limites dados, o desenvolvimento se faz mediante uma multiplicidade de cursos e trajetórias possíveis. Assim, o caminho a ser trilhado por um ser humano em desenvolvimento é, ao mesmo tempo, determinado e indeterminado. Ainda, segundo ele, essas coações não são estáticas e definitivas, pois encontram-se em contínua transformação, podendo existir a possibilidade de se ampliar e ultrapassar as delimitações anteriormente demarcadas.

Essa possibilidade de mudanças nas coações deve-se, em parte, à forma como, nas interações cotidianas, os instrumentos técnicos e semióticos são apropriados pelas pessoas. Pino (1995) entende que essa apropriação implica a ressignificação pelos sujeitos de algo que já tem um significado social. Para Valsiner (1988), essa ressignificação resulta da elaboração pessoal da cultura social, durante o desenvolvimento da história de vida de uma pessoa particular. Isso induz a uma miríade de formas individuais únicas de "culturas pessoais", presentes em uma sociedade, (re)estabelecendo novos significados e novos limites.

Finalmente, na medida em que o desenvolvimento se dá dentro de uma natureza relacional organismo-ambiente (Valsiner, 1987), este último também se transforma contínua e dinamicamente, do mesmo modo com que se modificam dialeticamente as relações indivíduo-meio. Assim, alguns aspectos do meio físico-social são importantes para um sujeito em determinada idade construir certas habilidades ou conjunto de significações. Mas, ao mesmo tempo em que aqueles aspectos são transformados pela ação e pelas significações dadas pelos sujeitos, em outros momentos, outros aspectos do ambiente surgem

1. O termo constraint contém um sentido de duplo movimento, sendo algo que, ao mesmo tempo em que restringe/ limita as ações, os pensamentos e os sentimentos possíveis, compele-os em determinada direção. Desta forma, entende-se o termo como coação. 
como novas fontes privilegiadas de promoção de desenvolvimento, diante da transformação dos recursos individuais da pessoa e/ou do grupo (Wallon, 1986). Nesta concepção, portanto, o meio só pode ser definido em razão de um sujeito ou grupo de sujeitos específicos, com determinadas competências, interesses, objetivos, em um dado momento e contexto socioistórico.

Entendemos que, dada a extrema plasticidade do bebê humano, a partir de interações com outros membros da espécie, ele é capaz de adaptar-se aos mais variados contextos, tornando-se um representante de uma determinada cultura. E, ainda, que a característica humana básica é a imersão do ser humano em um mundo simbólico, nas e por meio das interações que são estabelecidas com diferentes parceiros, resultando em uma contínua construção de significados, conhecimentos, sentimentos e em sua própria constituição como sujeito (Vygotski, 1991).

Nesse sentido, compreendemos que o ingresso na creche implica que os pais confrontem-se com toda uma malha de significações próprias da cultura em que estão inseridos e por aquelas construídas ao longo de sua própria história de vida. Ao mesmo tempo, a inserção na creche implica que bebês e familiares passem a encontrar-se imersos em um novo meio físico, social, ideológico e simbólico. Esse novo contexto irá propiciar novos contatos e experiências, além de capturar, confrontar e criar continuamente novos significados, promovendo novos recursos pessoais.

Para o bebê, diante de sua imaturidade, o "outro", em especial o adulto (familiares e educadoras), vai exercer um papel de mediador nesse processo de construção de significados (Wallon, 1986a), apresentando e significando as novas experiências, incluindo seu ingresso na creche e a separação temporária e diária da mãe. Para esses adultos há que se considerar, também, certas diferenças quanto às suas possibilidades de mediação, já que os familiares são aqueles que melhor conhecem o bebê e quem têm um maior investimento afetivo nele. Por outro lado, os educadores têm um conhecimento mais extenso de como se cuida coletivamente de bebês, devido a sua experiência profissional e a sua formação como educador.

É essa malha de sujeitos, relações e contextos, carregados de significações pessoais e coletivas, na situação de inserção de bebês na creche, no atual momento histórico e cultural, que nosso estudo buscou apreender.

\section{O PROJETO DE INVESTIGAÇÃO: "PROCESSOS DE INSERÇÃO DE BEBÊS NA CRECHE}

Partindo-se das concepções acima expostas, o Centro de Investigações sobre Desenvolvimento Humano e Educação Infantil (CINDEDI) vem desenvolvendo o Projeto Integrado "Processos de Adaptação de Bebês à Creche". Estruturado por vários eixos específicos de pesquisa, o objetivo geral foi estudar os processos que se desenvolvem a 
partir da inserção de bebês na creche, com a integração da criança, da família e das educadoras, à nova situação (Rossetti-Ferreira, Amorim e Vitória, 1994).

Essas investigações baseiam-se em registros relacionados ao ingresso e à freqüência de 26 bebês (5- 18 meses), a partir de março de 1994, na Creche "Carochinha", da USP de Ribeirão Preto.

Essa é uma creche universitária e encontra-se em funcionamento desde 1985. A admissão das crianças é realizada por órgão da Universidade (Coordenadoria de Assistência Social - COSEAS) e obedece a critérios socioeconômicos, dedicando 70\% das vagas aos funcionários e 30\% aos docentes e alunos (graduação e pós-graduação).

A direção da creche, em associação com o Centro de Investigações sobre Desenvolvimento Humano e Educação Infantil - CINDEDI -, tem elaborado um projeto social e pedagógico para essa instituição. Concebida como um local complementar à família, a creche compartilha com essa última a responsabilidade da educação da criança. E, pela organização do espaço e das atividades, busca favorecer as interações das crianças, tanto com os adultos, como com as outras crianças, oferecendo um contexto especialmente planejado para promover o desenvolvimento infantil.

A direção entende que o processo de inserção de bebês na creche usualmente ocorre com a emergência de intensas reações de ansiedade e culpa, especialmente por parte da mãe, acompanhadas de fortes conflitos entre os diversos membros familiares e, ainda, entre eles e os membros da creche. Assim, tem procurado fazer com que o ingresso das crianças ocorra da forma mais positiva possível, tanto para a criança e sua família, como para as educadoras envolvidas. Para isso, planeja o acolhimento às crianças e a seus familiares de forma a promover o conhecimento e a confiança mútua, buscando ainda favorecer a integração e o estabelecimento de vínculos entre os familiares e as educadoras (para maiores detalhes, vide Vitória, Rossetti-Ferreira, 1993 e Rossetti-Ferreira, Amorim, Vitória, 1997).

Visando à efetivação do estudo, a equipe de pesquisa realizou reuniões com a direção da creche, com as educadoras e com as famílias, quando apresentou-lhes o projeto e obteve as autorizações para o registro da situação. Esse registro foi feito, ao longo de todo o ano de 1994, a partir de fichas de identificação das crianças (do tipo anamnese) e de suas famílias, além de fichas diárias de freqüência, de estado de saúde, de intercorrências médicas e de observação do comportamento da criança. Foram realizadas, também, entrevistas com as educadoras, com as técnicas (psicóloga, nutricionista e auxiliar de enfermagem) e com as mães (somente das crianças consideradas "sujeitos focais", como será discutido adiante). Finalmente, durante os três primeiros meses de freqüência das crianças à creche, foram feitas gravações em vídeo das interações ocorridas no ambiente do berçário.

Os sujeitos do estudo foram os 26 bebês (5- 18 meses de idade), seus familiares e as educadoras. As crianças começaram a freqüentar a creche entre março e abril de 1994 , acompanhadas de seus familiares, entrando gradualmente em contato com as respectivas 
educadoras. Oito desses bebês foram considerados "sujeitos focais", sendo investigados mais intensamente.

Com o conjunto de trabalhos em andamento, iniciamos ampla discussão sobre os fatores envolvidos no processo de integração desses sujeitos, nesse ambiente. Destacamos alguns elementos como centrais ao desenvolvimento desse processo, a partir dos quais listamos vários conjuntos de fatores. Buscamos, finalmente, identificar como eles se relacionavam e se articulavam.

A análise dos elementos que potencialmente atuam sobre a situação e a verificação de sua inter-relação em uma rede de fatores levou-nos a reconhecer a existência de uma proximidade com a Pesquisa Ecológica de Desenvolvimento Humano, de Bronfenbrenner. Antes, pois, de discutirmos nossa perspectiva teórico-metodológica, achamos interessante apresentar brevemente a proposta de Urie Bronfenbrenner.

\section{Pesquisa Ecológica de Bronfenbrenner}

O Sistema Ecológico de Bronfenbrenner (1977, 1986, 1993 e 1996) é uma proposição que tem por objetivo investigar o desenvolvimento humano em contexto. Isto é, estudar cientificamente o desenvolvimento do organismo humano - considerado ativo - na interação com seu ambiente, ambos em transformação.

Segundo o autor, o desenvolvimento envolve processos de mudança, com a emergência de padrões duradouros de comportamento e percepção. Ele resulta do jogo entre as características biológicas da pessoa e do ambiente onde vive, o que cria estruturas dinâmicas que envolvem três ou mais pessoas, em intensa bidirecionalidade e reciprocidade de influência, em sistemas que se modificam através do tempo.

As pessoas são consideradas como organismos funcionais integrados num todo, onde os vários processos psicológicos - cognitivos, afetivos, emocionais, motivacionais e sociais - operam em interação coordenada. E, fundamentalmente, o processo de desenvolvimento é entendido como afetado pelas relações que ocorrem tanto dentro do setting ${ }^{2}$ imediato que a pessoa se encontra, como entre os vários settings que ela freqüenta, assim como pelos contextos sociais mais amplos.

O conjunto de settings e contextos, denominado por ele de ambiente ecológico, é concebido topologicamente como um arranjo de estruturas interdependentes, que devem ser analisadas como sistemas. Alguns desses settings contêm a pessoa e, diretamente, influenciam-na e são influenciados por ela (micro e mesossistemas). Outros não contêm diretamente a pessoa, mas agem sobre, ou envolvem, o setting imediato no qual a pessoa se encontra e, portanto, influenciam, delimitam ou mesmo determinam o que nele acontece (exo e macrossistemas).

2. O setting, segundo Bronfenbrenner, é constituído pelos fatores lugar, tempo, características físicas e simbólicas, participantes, atividades desenvolvidas e papéis desempenhados. 
Brevemente, Bronfenbrenner concebe microssistema como o complexo de relações entre a pessoa em desenvolvimento e o setting imediato que a contém. Como exemplo, o autor cita a casa, a creche ou a escola.

O mesossistema compreende as inter-relações entre os principais settings que contêm a pessoa em desenvolvimento, em um ponto particular em sua vida. Constitui um sistema de microssistemas, com influências diretas e indiretas, ou de segunda ordem. Como exemplo, ele refere que o mesossistema típico para uma criança americana de 12 anos envolve interações entre a família, a escola e seu grupo de parceiros de idade. Para algumas crianças pode, também, incluir a igreja, o campo, a força de trabalho.

O exossistema é uma extensão do mesossistema, envolvendo outras estruturas sociais específicas, tanto formais, como informais. Estas envolvem o mundo do trabalho, a vizinhança, a mídia, agências governamentais etc. Para Bronfenbrenner, esse sistema envolve ligações e processos que acontecem entre dois ou mais settings, sendo que pelo menos um deles não contém a pessoa em desenvolvimento, mas que indiretamente influenciam os processos dentro do setting imediato no qual a pessoa em desenvolvimento vive. Como exemplo, ele cita o impacto do status de trabalho da mãe e do próprio local de trabalho da mãe sobre a criança, apesar de esta não participar diretamente do trabalho.

E, finalmente, Bronfenbrenner trata do macrossistema, que se refere a padrões institucionais da cultura ou subcultura, tais como sistemas econômicos, sociais, educacionais, políticos, dos quais o micro, o meso e exossistemas são manifestações concretas. Esse sistema difere de modo fundamental dos anteriores, já que não se refere a contextos específicos afetando a vida de uma pessoa em particular, mas a protótipos gerais existentes na cultura ou subcultura que firmam o padrão de estruturas e atividades que ocorrem em um nível mais concreto. São carregadores de informação e ideologia (freqüentemente inconscientemente nas mentes dos membros da sociedade), tanto implícitas (costumes e práticas no dia-a-dia), como explícitas (leis, regulamentos e regras), além de significados e motivações.

Entendemos, dessa forma, que a proposição de Bronfenbrenner procura estudar o processo de desenvolvimento de modo que abarque o sistema pessoa-processo-contexto. Procura, ainda, superar os modelos de investigação estruturais, até então predominantes na Psicologia do Desenvolvimento, em direção a estudos processuais.

Porém, em nossa leitura, apesar dos avanços que sua teoria traz, a estrutura é, ainda, o elemento de destaque, no qual o processo de desenvolvimento se dá, possibilitando a discussão dos vários níveis de fatores envolvidos na situação. Sentimos, assim, que ela não dá conta de dois aspectos considerados centrais à nossa perspectiva: I) do tempo que transcorre e dos processos de transformaçã̃o que ocorrem ao longo do mesmo; 2) da dinâmica e contínua emergência de significações, isto é, dos elementos semióticos, que se apresentam ao longo de todo o processo e que envolvem os respectivos fatores.

Uma comparação mais clara entre a proposição de Bronfenbrenner e nossa 
perspectiva é entendida como um passo importante dentro da proposta em curso. Porém, ela se fará em outro momento e a partir da continuidade do aprofundamento teórico e da análise de dados empíricos.

Caminhamos, pois, no sentido de elaborar uma perspectiva teórico-metodológica mais específica, a que denominamos de "Rede dinâmica de fatores na qual ocorrem os processos de adaptação da criança, da mãe e das educadoras, após a inserção de um bebê na creche" (Rossetti-Ferreira, Amorim e Vitória, 1996 e 1997). A apresentação dessa rede de fatores, como dito anteriormente, constitui o foco deste artigo.

Importante mencionar que as questões a serem abordadas aqui levarão em consideração, de forma integrada, além da investigação em curso, a experiência do CINDEDI obtida em outras pesquisas e atividades de ensino, de estágio e de intervenção na área (assessorias e consultorias em creches, além de projetos psicopedagógicos elaborados em conjunto com a Creche "Carochinha" da USP de Ribeirão Preto). Porém, a apresentação será feita, fundamentalmente, mediante o corpus obtido em dois estudos de caso, de sujeitos focais da investigação: Mãel (MI) e seu bebê de cinco meses ao ingresso e Mãe2 (M2) e seu bebê de nove meses no início de freqüência à creche, além das educadoras das crianças.

\section{Rede dinâmica na qual ocorre o processo de inserção de bebês na creche}

De modo a estruturar a análise dos dados, decompusemos artificialmente os vários elementos da situação empírica, os quais englobam os componentes individuais dos três principais participantes envolvidos na situação ( $M$ - mãe, B - bebê e $E$ - educadora). Esses componentes abrangem características de ordem biopsicossocial, tanto passadas, como presentes, assim como perspectivas futuras, constituindo e sendo constituídas por campos interativos e cenários. Os campos interativos referem-se aos vários relacionamentos e interações que são ou podem vir a ser estabelecidos entre os sujeitos \{MãeBebê\}, \{Educadora-Bebê\}, \{Mãe-Educadora\} e \{Educadora-Educadora\} \{BebêBebê\}. Esses campos revelam-se estreitamente interligados e imersos em redes sociais mais amplas, as quais denominamos cenários e que, na situação em análise, referem-se fundamentalmente à creche e à família.

Em cada um dos elementos acima especificados (componentes individuais, campos interativos e cenários), procuramos identificar quem participou da situação; quando, onde e como as interações ocorriam; e as concepções, representações sociais e relações afetivas predominantes.

Finalmente, entendemos que todo este conjunto encontra-se impregnado, significado e transformado por uma matriz socioistórica, constituída por um complexo contexto econômico, político, social e cultural. Essa matriz, seja compreendida como fundamentalmente semiótica, e ao mesmo tempo significativa dos vários elementos e o conjunto da situação, é também ressignificada e transformada por eles. Entendemos, ainda, que ela 
muda conforme o contexto e as interações e, particularmente, pelos papéis e contrapapéis que as pessoas assumem, negam e/ou recriam, nos diferentes momentos e contextos histórico-sociais e individuais (Oliveira, 1988 e 1995; Oliveira, Rossetti-Ferreira, 1994).

A dinâmica e dialética interação entre todos os elementos acima descritos é concebida como uma rede de significações, esquematizada na figura $I$.

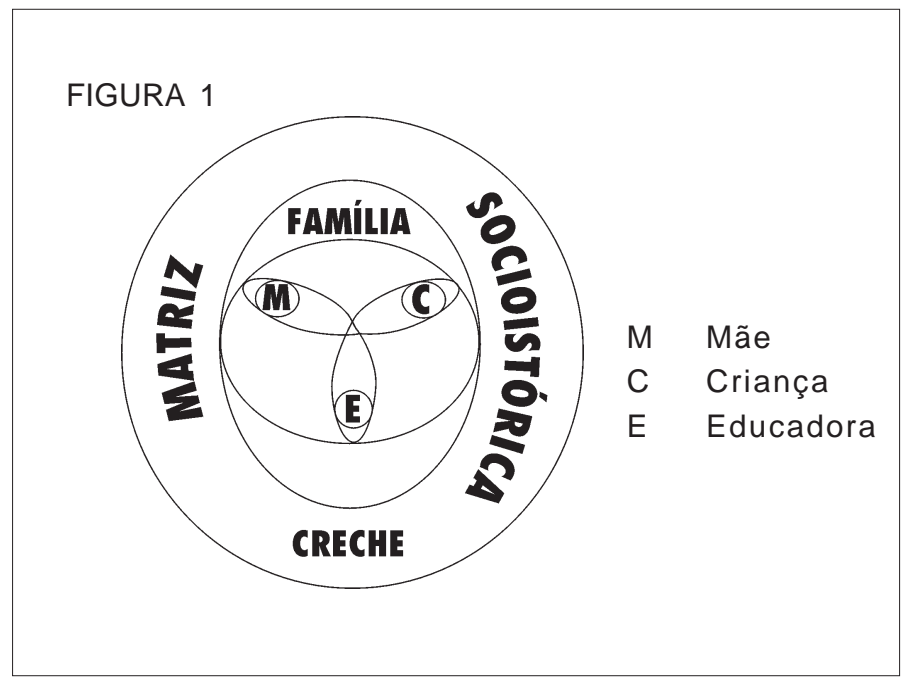

A seguir, especificaremos com maior pormenor os diferentes elementos desta figura, considerando o estudo do processo de inserção de bebês na creche.

O cenário da família é um espaço basicamente privado e envolve não apenas os familiares, como também o círculo de amigos/de vizinhança e é definido pela articulação entre vários elementos: ambiente físico, pessoas que o compõem, relações afetivas e sociais que se estabelecem entre elas, papéis, rotinas, práticas e cultura familiar. Quanto ao último aspecto, destacamos como relevante para nossa discussão as concepções sobre a maternidade, sobre a mulher como profissional e sobre a educação de crianças pequenas. Esse cenário é bastante influenciado pelo tipo de inserção da família no esquema de produção, sendo que as características do trabalho pelo qual essa família se sustenta e em torno do qual se organiza irão, predominantemente, estruturá-lo.

Entendemos que diferentes ambientes propiciam diferentes condições de desenvolvimento, por favorecerem modos diferentes de interação e de experiências. Obviamente, práticas sociais diversas são encontradas nas diferentes camadas sociais e, mesmo, dentro de cada uma, a depender das condições atuais de vida e da história de uma família, assim como da história do grupo, etnia, cultura etc. 


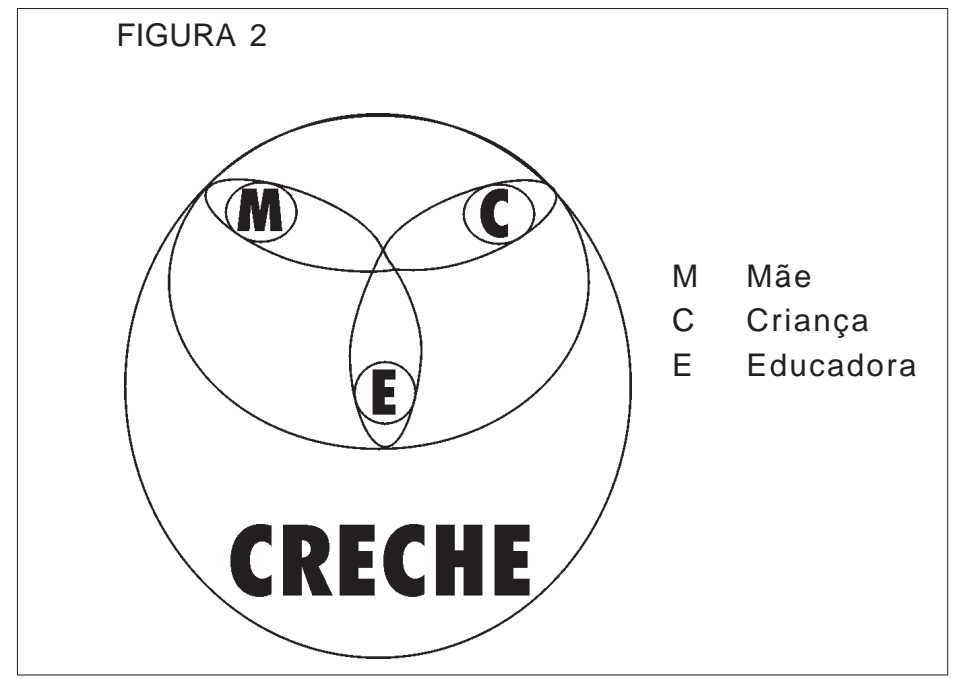

O cenário da família é constituído pela rede familiar e social mais ampla e é freqüentado por várias pessoas (tais como pai, avós, irmãos, tios, padrinhos, amigos etc.), entre as quais é comum estabelecerem-se relações afetivas intensas, que envolvem tanto aspectos positivos, como negativos. Para a análise específica da inserção de bebês em creche, destacamos como mais relevante a relação da díade \{Mãe-Criança\}.

A busca de soluções alternativas e complementares aos cuidados dos filhos leva a família a contar com diferentes redes de apoio, as quais irão possibilitar formas variadas de cuidado das crianças. As condições materiais, as concepções sobre desenvolvimento infantil, as expectativas e os planos que os pais têm para essa criança influenciam suas decisões e ações quanto ao contexto desenvolvimental que irão prover para ela. Isso envolve a possibilidade de deixá-la, ou não, na creche, bem como o tipo de relacionamento que estabelecerão nesse ambiente específico.

Muitas vezes, a decisão de colocar o filho na creche contrapõe-se às concepções e expectativas dos familiares, o que resulta em um processo tenso e cheio de conflitos. Em nosso material de pesquisa, uma das mães (Mãel) resgatou, em uma mesma entrevista, um grande número de discursos, sejam diretos ou indiretos, que revelavam a penosa e ambivalente decisão de deixar a filha de cinco meses de idade na creche:

- "Quem vai pegar ela, quando ela chorar? Como que vai ser? Vai ficar só no bercinho?" (Mãel relata comentário de Pail)

- "Creche é tudo igual. A creche judia, tadinha!" (Mãel diz o que a sogra pensa sobre a creche) - "Você vai ver... Você vai sofrer tanto, que vai ter vontade de pegar ela e não deixar mais ela lá." (Mãel menciona comentário de interlocutor não identificado) 
- "O pediatra dela disse que ela ia dar muito trabalho, podendo inclusive perder peso quando entrasse no berçário..." (Mãel relata fala do pediatra)

Esses discursos, nada favoráveis à colocação da filha na creche, provavelmente concorreram para a atitude de retraimento da mãe nesse ambiente. Ela procurava insistentemente isolar-se e isolar sua filha das demais pessoas presentes. À observação do vídeo, fica clara a atitude pouco responsiva da mãe às aproximações das educadoras, das outras mães e mesmo das outras crianças. Além disso, pela sua localização na sala (sempre em um mesmo local, mais afastado) e pelo posicionamento corporal em que colocava a filha (de costas para o ambiente e em uma posição onde a mãe era o que se apresentava no campo visual da bebê), parecia procurar manter a interação da díade \{Mãe-Criança\} como central, num ambiente onde tal centralidade não é esperada nem desejada.

No entanto, no mesmo período e ambiente, identificamos a existência de outras experiências e concepções ligadas à creche, fazendo com que outros familiares se posicionassem de maneira bastante diferente no processo de inserção do filho. A Mãe 2 (funcionária da própria creche) tem uma menina de nove meses de idade e confia muito no tipo de cuidado que a creche oferece à filha, já tendo tido, inclusive, experiência anterior de deixar uma filha mais velha no mesmo ambiente. Diz ela:

...ela [a criança] está sentindo que a creche é realmente o espaço que ela... que é dela, que é feito pra ela, né. Não é que nem em casa, que o espaço é mais de adulto. Aqui ela se sente, mesmo, muito à vontade de explorar os espaços... Chega fim-de-semana, dá até faniquito nela, porque aí ela já vê que num tá naquele espaço que ela gosta, né. Então, ela já diferencia bem a coisa... Ela adora vir pra creche, adora o espaço que ela tem... (Mãe 2)

Neste caso, observa-se, no vídeo, que a mãe acaba por realizar uma mediação mais positiva do novo ambiente, dos novos elementos e das outras crianças, procurando sempre apresentar as outras pessoas presentes, com destaque para as educadoras responsáveis pelo seu cuidado. De forma interessante, esse discurso da mãe nos soa, à primeira vista, como refletindo sua situação e relação com a criança. Como veremos adiante, está também repleto de conflitos e sugere a existência de vários outros sentidos.

A influência do grupo familiar tem relevância na situação, não apenas por ocasião do início da freqüência à creche. Pode, também, emergir diante de situações inéditas, durante o percurso da criança/família no ambiente. Um caso ilustrativo desse fato envolveu um bebê de dez meses de idade, que teve uma excelente adaptação inicial ao novo ambiente, destacando-se pela sua capacidade de interagir tanto com as crianças, como com os adultos. Após pouco mais de um mês, ao adoecer com gripe, iniciou terapêutica com um médico que, segundo relatou uma educadora, era radicalmente contra a freqüência da criança à creche. Ela foi retirada desse ambiente quando a avó materna, que já havia se posicionado contrariamente à sua inserção na creche, pára de trabalhar fora, a fim de cuidar da neta em casa. 
É no cenário da família que se insere, de forma privilegiada, o campo \{MãeCriança\}, no qual, para a faixa etária considerada neste estudo, destacam-se as relações de apego. Essas podem envolver algumas pessoas com as quais a criança mantém interações afetivas, embora, em nossa cultura, a figura central de apego seja usualmente a mãe. As relações de apego têm um curso de desenvolvimento bem estudado em várias culturas, evidenciando-se, de forma mais clara, em torno de cinco a seis meses de idade. A partir desse momento, até os dois anos, intensificam-se os protestos e reações pela separação e busca de proximidade da figura de apego, especialmente em ambientes novos para a criança (Rossetti-Ferreira, 1984).

Neste estudo, no qual os bebês contam entre 5 e 18 meses de idade, observamos que o campo \{Mãe-Criança\} é particularmente afetado quando ocorre $\circ$ ingresso na creche. Identificamos alguns bebês que demoraram mais para começar a explorar o ambiente estranho, mesmo na presença da mãe, enquanto outros reagiam com maior desenvoltura. Além disso, vimos que algumas das crianças reagiam negativamente ao reencontro com a mãe, enquanto outras tinham uma manifestação bastante positiva. Por outro lado, algumas mães demonstraram maior satisfação perante uma reação de maior independência de seu filho, enquanto outras mostravam-se mais inseguras em relação à separação, mesmo que por um curto período do dia. Assim, as formas de apego desenvolvidas na relação mãe-bebê, classificadas por Ainsworth et al. (1978) como diferentes padrões de apego (seguro e inseguro), puderam ser observadas em nosso material, conforme as reações do bebê diante do novo ambiente, da separação e do reencontro com a mãe. Porém, a interpretação desses comportamentos ainda hoje é objeto de investigação e discussão em nosso grupo, já que se mostram intensamente influenciados pelo modo como a mãe reage, como a relação \{Mãe-Criança\} se constrói, pelo próprio contexto da creche e, ainda, pela reação da profissional mais ligada à díade.

Um exemplo interessante da manifestação do apego na relação \{Mãe-Criança\} pode ser visto no caso da Mãel, a qual manifestou grande dificuldade e ambivalência em deixar a filha de cinco meses na creche. Em sua história anterior, encontramos uma convivência muito íntima entre as duas. Ambas não tinham, praticamente, experienciado nenhuma separação anterior. A mãe era estudante de graduação e após o nascimento da criança, que se deu durante o período letivo, a menina chegou a freqüentar a sala de aula na faculdade. Logo depois, inicia-se o período de férias e a mãe fica todo o tempo dedicada à filha. A inserção dessa criança na creche, após esse período, representou o primeiro momento efetivo de separação entre elas, além de implicar que outras pessoas passaram a participar dos cuidados da menina. Essa situação foi potencializada pelo fato de ter ocorrido aos cinco meses de idade, fase em que os protestos da criança à separação da mãe se intensificam (Spitz, 1979), provocando no bebê uma forte reação à separação e à ausência da mãe. Para esta, que carregava concepções de cuidado infantil muito associadas à maternagem, a forte reação de choro da criança tornou o momento muito difícil: "... estava 
sendo difícil para a nenê... Mas, sei que é por necessidade... Não! É o melhor que eu podia estar dando para ela agora. Eu não posso ficar me culpando..."

A separação da filha foi, inclusive, vivenciada pela mãe com o temor da perda do amor da criança por ela: "Está mais solta, não tá tão grudada em mim, vai para outras pessoas... A gente fica um pouquinho assim: 'será que ela não vai me olhar, um pouquinho, na hora do almoço?"”

No caso da Mãe 2 (funcionária da creche), o ingresso da filha no ambiente ocorreu de forma bastante diversa. A Mãe 2 já havia retornado ao trabalho, há alguns meses, e a criança ficava em casa, sob os cuidados de uma babá. Portanto, a menina já não permanecia o dia todo junto à mãe e vivenciava situações diárias de separação. Durante a primeira semana de freqüência à creche, como a mãe desempenhava funções profissionais no ambiente, foi a babá quem acompanhou a menina à creche. Deste modo, o fato de elas se separarem por algumas horas durante o dia e de a criança ficar sob os cuidados de outras pessoas pareceu não ter um efeito dramático sobre o relacionamento. Porém, o campo \{Mãe-Criança\} foi seriamente afetado pelo fato de a Mãe 2 desempenhar, no ambiente da creche, um duplo papel - o de mãe e o de profissional (funcionária da creche) - e de que o trabalho tinha para a mãe um significado bastante forte. Apesar da presença materna no ambiente de cuidados da filha, ela não se dedicava exclusivamente a ela, encontrandose sempre ocupada com as outras crianças, famílias e educadoras. Ela não conseguia permanecer tranqüila com a filha, esquivando-se, muitas vezes, de um contato mais próximo. Relata nas entrevistas que, devido ao seu papel, procurava estabelecer limites no relacionamento com a criança naquele ambiente:

... deixo muito claro esse limite pra ela, que é um limite que eu tenho e que comigo eu num admito que aconteça... Porque quando eu tô trabalhando, também eu não ligo mesmo... ela pode morrer de querer. Nessa hora, eu num tô podendo, né. (...) Ela já tá começando a perceber que a hora que eu tô trabalhando, eu tô trabalhando, e a hora que eu venho pra dar um carinho pra ela, é a hora que eu venho pra dar um carinho pra ela. Tem essa diferença, então ela num entra muito nessa comigo. (M 2)

Toda essa situação promoveu uma rearticulação do campo \{Mãe 2-Criança\} até então existente. E, como pode ser observado no vídeo, a menina passou a ficar grande parte do tempo sentada no chão, olhando para o ambiente, procurando verificar se a mãe estava presente e ir em sua direção (engatinhando) sempre que a via. Como esse "estar com a mãe" naquele ambiente nem sempre era possível, a criança passou a ficar chorosa e a requisitar, continuamente, o colo de suas educadoras ou mesmo de outros elementos presentes.

Consideramos, desse modo, que as verbalizações da mãe sobre a tranqüila permanência de sua filha na creche (apresentadas anteriormente) representaram uma racionalização do problema. A mãe em sua fala destaca, exclusivamente, o aspecto do prazer da 
criança e de sua independência no ambiente da creche, apresentando dificuldades em identificar e reconhecer os conflitos que emergiram na situação.

Percebe-se que, para os familiares, são fundamentais o significado da creche e o papel que eles desempenham naquele ambiente, freqüentemente permeado por conflitos. Por meio desses significados e das necessidades da mãe, são elaboradas interpretações quanto às suas próprias ações, às da criança e às das educadoras; às interações em construção \{mãe-filho\} e àquelas que envolvem a criança e a mãe com as educadoras e com outras crianças e familiares no ambiente. Esses significados representam, ainda, a base para a elaboração do questionamento da creche como ambiente saudável para o filho, com a promoção, ou não, da presença do filho nesse novo meio e de sua independência nele.

Vejamos, agora, o cenário da creche. Nele estão inseridos os campos \{Educadora-Bebê\}, \{Mãe-Educadora\} \{Bebê-Bebê\} e \{Educadora-Educadora\}. Nesse cenário, podem também ocorrer, dependendo das relações creche-família, as interações ligadas ao campo \{Mãe-Criança\}.

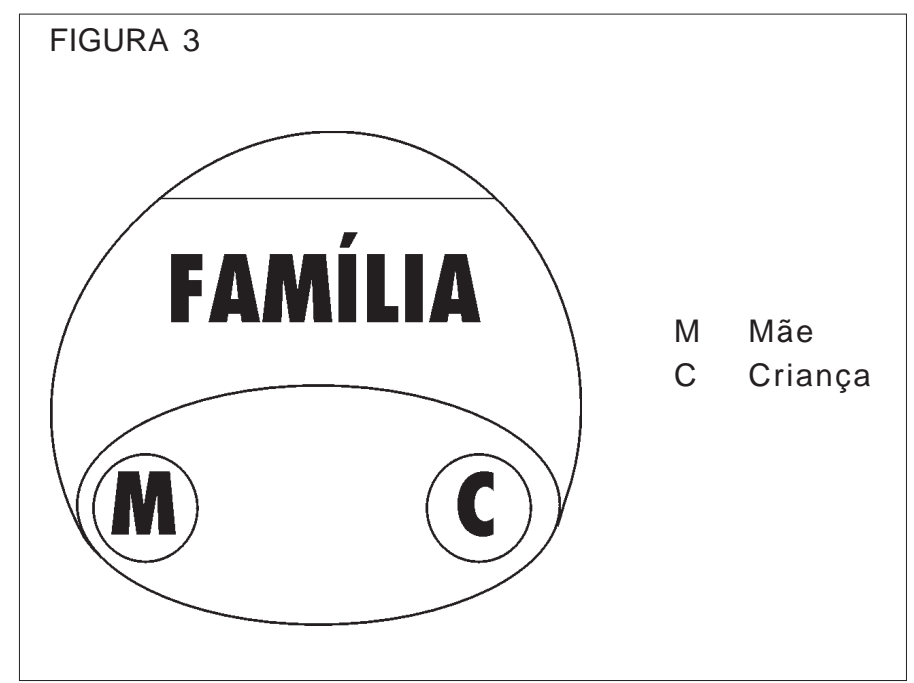

As características desse cenário podem ser bastante variadas, a depender da proposta de atendimento, e estão intimamente relacionadas à clientela-alvo e às concepções que a direção tem de bebê, de desenvolvimento infantil e da função da instituição. As concepções definem, ainda, os tipos de profissionais responsáveis pelas crianças, sua qualificação, razão adulto/criança, programação para cada grupo e característica dos relacionamentos estabelecidos com a criança e a família. Os recursos de que a creche dispõe, particularmente para manter o quadro de pessoal, constituem outro fator importante, intrínseco à caracterização do serviço que é prestado. 
A depender desse conjunto de fatores, as creches têm-se estruturado por um atendimento de cunho mais assistencialista, médico-higienista ou pedagógico. Entretanto, é preciso mencionar, neste tópico, que as características desses diferentes tipos de atendimentos não envolvem necessariamente um "degradê de qualidade" e nem que a visão educativa é "redentora" da assistencial. Entendemos, sim, que todas elas devem ser vistas como capazes de exercer funções complementares e que a própria assistência pressupõe uma concepção educativa específica (Kuhlmann, 1998; Rocha, 1999). Obviamente, diferentes concepções e modelos coexistem em uma mesma instituição, harmonizando-se ou, mesmo, confrontando-se entre si.

A noção que a família tem da instituição assume uma forma mais concreta apenas após o início da freqüência dos pais/bebês à creche. No entanto, a evolução dos comportamentos e das relações nesse ambiente tem rumos diversos, a depender dos fatores que atuam sobre a situação. A família que nunca teve qualquer experiência mais próxima com uma creche irá se encontrar em um ambiente muito diferente, devido ao número de pessoas (adultos e crianças) com quem passa a conviver, além das próprias regras institucionais. É provável que essa família tenha que rever suas expectativas e seu próprio papel em relação à criança e, ainda, com o ambiente da creche. No caso abaixo, temos o registro da manifestação da Mãe I, a qual havia chegado à instituição com grandes preconceitos sobre a creche:

- Lá deram folhetinho, fizeram entrevistas, falaram do problema da adaptação e foi tranqüilizando mais. A noção de creche não é bem aquilo, que a criança fica jogada lá, só dando comida. Mas, não bastou folheto, entrevista... foi importante ver como é que é!

Neste caso específico, essa mãe teve a oportunidade de integrar um cenário diferente da sua expectativa, onde pôde interagir com outras mães que passavam pelo mesmo processo ou que tinham filhos mais velhos na creche e estavam em processo de adaptação do segundo ou terceiro filho: "É um outro grupo de amizades que a gente faz lá, com outros pais.... Amplia os relacionamentos. Eu tenho pensado nisso... nós vivemos momentos parecidos e é uma troca muito gostosa" (Mãel).

○ cenário da creche pode ser um palco para as interações \{Mãe-Criança\}, a depender das relações creche-família e da existência de um consentimento, pela instituição, da presença da mãe dentro do ambiente de cuidados do filho. Entretanto, a maioria das creches tende a não permitir o livre acesso das mães e outros membros familiares ao seu interior, muitas vezes, para evitar conflitos e dificuldades decorrentes de maior aproximação entre as famílias e o pessoal das creches. Isso pode dificultar um desenvolvimento mais positivo e efetivo das relações creche-família, no sentido de colaborarem juntas para o bom desenvolvimento da criança.

No cenário da creche insere-se, fundamentalmente, o campo \{Educadora-Criança\} e o ambiente desse campo é constituído pelo(s) local(is) em que ocorrem as atividades 
com aquele grupo de crianças. No caso de "berçários", stricto sensu, esse ambiente se restringe com freqüência a uma única sala repleta de berços, nos quais os bebês permanecem praticamente o dia todo, e a educadora constitui-se no elemento destacado de interação com a criança. Na Creche "Carochinha", no entanto, o espaço é organizado com várias salas e as crianças permanecem basicamente no chão. Isso promove não só maior autonomia e desenvolvimento neuromotor, como privilegia outras relações, sobretudo entre as crianças, mesmo no primeiro ano de vida. Assim, o local varia muito de creche para creche e, evidentemente, cada ambiente irá prover interações diversas e oportunidades diferentes de desenvolvimento.

Nesses ambientes, a construção do vínculo afetivo entre a criança e a educadora responsável constitui um processo gradativo e exerce um papel central na inserção da criança no novo ambiente, particularmente nos primeiro e segundo anos de vida. Essa construção é mediada pelas relações que se estabelecem entre a mãe e a educadora, pelos membros da equipe da creche (coordenadora, técnicos) e pelo programa educacional, o qual é planejado de acordo com a faixa etária das crianças a que atende e se traduz em rotinas de atividades específicas.

A integração \{Educadora-Criança\} pode ser, inicialmente, difícil. As reações das crianças diante da nova situação e do processo de construção das novas relações estão ligadas às experiências recentemente vividas e apresentam-se como elementos muito concretos: a rotina de cuidados, o cheiro de sua mãe e de sua casa, o sabor do bico do seio da mãe, da chupeta e da mamadeira; a temperatura, a luminosidade e as cores do ambiente, o número de pessoas com quem convive, os sons das vozes, o modo como a seguram e tocam etc. Os exemplos, a seguir, ilustram alguns desses aspectos:

- ... está chorando... você dá a chupeta pra ela... não tem negócio. Só se for dormir... Ela quer dormir: qual que é a dica dela? Ela te mostra a chupeta, ela te mostra o paninho e a água. E a água, né. Se você der leite... enquanto você não der água, cê não tem negócio nenhum com ela. Se você der a água é mesma coisa que dar um calmante. (Educadora 3 comenta a respeito de criança de dez meses)

- ...no começo a gente tava até brincando, que eu ia comprar uma meia preta, porque era assim, ela agarrava as perna da Diva o tempo inteiro. Aí eu falei assim: "Vou comprar uma meia fumê. Vocês vão ver se ela não vai 'uap', correr nas minhas pernas". (Educadora 3 é branca; Diva, a mãe e a criança são negras)

As reações e respostas das educadoras perante as diferentes exigências feitas pelas inúmeras crianças que têm para atender e o suporte que essas educadoras recebem da direção e da equipe técnica da instituição são fatores que podem facilitar ou dificultar a construção do vínculo entre educadora e criança e, mesmo, influenciar a qualidade da relação:

- Demora um tempo para você se adaptar com a criança. Não é "Ah! Já sei como cuidar dela". Não 
é, porque cada dia é uma surpresa. (Educadora 2)

- Mas são tantas coisinhas. Se a gente não tá atenta... Até cê descobrir... até descobrir, a criança

já... já se irritou. (Educadora I)

A construção do campo \{Educadora-Criança $\}$ faz-se por meio de inúmeras interações no dia-a-dia da creche e mostra-se bastante dinâmica, ainda mais no caso de crianças no primeiro ano de vida, quando o rápido desenvolvimento neuromotor promove alterações profundas, em um tempo muito curto. Esse aspecto foi bastante observado na fala das educadoras, como mostra o exemplo abaixo:

É até engraçado de como a criança muda totalmente em um mês. A Linda chegou era uma criança... ela não engatinhava, ela só se arrastava. Aí, na primeira semana, ela já começou a engatinhar. Ainda a avó brincou com ela assim: "Ah! Ela ficou com vergonha. Chegou lá na creche todo mundo engatinhava e ela... ela resolveu treinar em casa e começar a engatinhar". Em uma semana... menos de uma semana, porque ela entrou na segunda, na terça-feira ela já tava engatinhando. Então foi assim uma coisa rápida demais. (Educadora 4)

campo \{Educadora-Criança\} é bastante influenciado pelas relações que se estabelecem entre a mãe/familiares e essas educadoras e pela ação mediadora da mãe na interação da criança com a educadora. Mãel, por exemplo, buscando promover a exclusividade da relação \{Mãe-Criança\}, ficava com a filha na hora do almoço, dava-lhe comida, amamentava e a colocava para dormir. Quando a criança acordava, no final da tarde, a mãe já estava voltando para buscá-la. Esse comportamento da mãe foi irritando a educadora responsável pelos cuidados da criança, desse período, já que com essa rotina ela não conseguia estabelecer com a criança um contato mais efetivo. Em situações de maior dificuldade como essa ou quando, por motivos próprios, a educadora não está sabendo lidar com uma determinada situação, membros da equipe da creche (coordenadora e técnicos) podem auxiliar no processo orientando, agindo em conjunto ou servindo como apoio à situação. Evidentemente, a ação dos técnicos e, principalmente, das educadoras é, também, influenciada por suas expectativas e suas experiências pessoais e profissionais.

○ campo \{Mãe-Educadora\} concretiza-se e desenvolve-se, basicamente, no cenário da creche. Porém, envolve um conjunto mais amplo de elementos, abrangendo as outras mães e familiares das crianças e de outras turmas, além dos vários profissionais da creche.

Os espaços onde entregam e buscam os filhos e os locais de reuniões constituem os ambientes nos quais, mais freqüentemente, ocorrem os encontros. Entretanto, não é incomum que as educadoras e mães morem no mesmo bairro ou tomem uma mesma condução para ir e voltar da creche ou do trabalho, encontrando-se, pois, fora da instituição. Além disso, muitas creches atendem aos filhos dos próprios funcionários, e um contato prévio com as educadoras de seu filho já está bem estabelecido. No entanto, essa 
proximidade mãe/educadora/colega de trabalho, além da duplicidade de papéis no mesmo ambiente (mãe/profissional), pode tornar-se uma fonte de conflitos. Eles podem expressar-se na relação da mãe com a criança, como observado acima no caso envolvendo a Mãe 2, e, mesmo, no relacionamento entre as educadoras e a mãe.

As relações creche-família, definidas pela direção administrativa, é que irão determinar, basicamente, o campo \{Mãe-Educadora\}. A creche pode ser relativamente fechada às famílias e o contato ocorrer apenas na porta da entrada, no momento da chegada e da saída das crianças ou, ainda, em reuniões formais. Por outro lado, a creche pode ser aberta à família, acolhendo habitualmente a mãe/familiares dentro do recinto ou mesmo na sala da criança. Pode, ainda, caracterizar-se por adotar normas e posturas que permitem que o trabalho se mostre mais ou menos transparente aos pais.

As relações entre creche e família dependerão dessas diferentes formas de organização da creche, podendo ser esporádicas e distantes, ou bastante próximas e cheias de emoção. Compartilhar o cuidado de bebês de uma maneira bastante aberta dá espaço para o aparecimento de emoções e conflitos, sobretudo em uma sociedade em que ainda prevalece a idéia de que a mãe é quem deveria cuidar do filho. Exemplos de conflitos no campo \{Mãe-Educadora\} podem ser observados nos comentários abaixo:

- A mãe pediu para eu cuidar da nenê como ela [a mãe] cuida! Aí eu falei: Na sua casa, pelo que eu sei, só tem ela de criança; tem a vó, tem a mãe... eu acho que aí vai ser um pouco difícil tá cuidando dela, exatamente como você cuida, porque aqui é coletivo, né? Eu tenho seis crianças... E no berçário, também, eu não tenho só seis, são responsabilidade direta minha, mas o conjunto é nosso... Então, fica meio difícil afirmar pra você que eu vou cuidar dela exatamente como você... Aí eu pensei: "Meu Deus, como essa mulher vai querer que eu cuide exatamente como ela cuida, se eu nem conheço ela e nem conheço a menina?" (Educadora 3)

- Ai, nossa, mas você faz assim? Poxa, nunca fiz assim, sempre fiz assim... Mas, assim você consegue? (Educadora 2 relata comentários de uma das mães)

- Parece que ela questiona muito a postura do educador. Se viu, se não viu... Ah! Eu falei: "Gente ...mas pera aí, nós só tamo com esse pingo de criança, por que... por que essa mulher questiona tanto se a gente viu ou deixou de ver?" (Educadora 4)

São conflitos inevitáveis, diante da diversidade de papéis e mesmo de conceitos, rotinas e práticas, fato reconhecido por uma das educadoras:

- Não, ela [bebê] tá ótima. Ela tá tranqüila. Ela não sei o quê. E ela tá mesmo. Só que isso não garante que a mãe também esteja tranqülla. Porque a nossa visão de que a criança tá ótima nem sempre é a da mãe, né? (Educadora 4)

Consideramos importante um preparo e apoio às educadoras e mães no sentido de elaborarem esses conflitos, construindo entre si uma relação de confiança, respeito e efetiva colaboração (Vitoria, 1997). Esforços no sentido de solucionar os conflitos e mesmo 
impasses nesse campo devem se dar com o apoio da direção técnica da creche, além de reuniões com as educadoras e entre elas e os familiares:

- Aí a Arlene [auxiliar de enfermagem da creche] me passou que conversou muito com ela. Que parece que ela tinha algumas dúvidas em relação à creche. E que a Arlene expôs tudo o que realmente tinha que ser, como que era. Eu senti, assim, que agora ela tem uma outra visão da creche. (Educadora 3)

Verificamos, ainda, que a interação dos vários sujeitos envolvidos na situação e as relações entre os diferentes cenários podem apresentar significados diversos nos diferentes momentos do processo. Alguns desses significados são mais constantes e mostram-se mais característicos, mobilizando certas emoções e interações. A partir dos episódios analisados, entendemos que pelo menos três momentos podem ser considerados: I. A tomada de decisão, pela família, de colocar a criança na creche; 2 . O ingresso na creche e os primeiros dias de freqüência nela, com o estabelecimento de novas relações, a reorganização das relações afetivas anteriores, bem como das práticas/rotinas diárias; 3. A construção de novas relações e vínculos. Esse terceiro momento vai ser bastante influenciado pelas rápidas e profundas transformações das relações, em razão também de mudanças no desenvolvimento dos bebês.

Os componentes pessoais de cada sujeito central (Criança, Mãe e Educadora), por sua vez, também influenciam as interações estabelecidas na família e na creche. No caso da mãe e da educadora, esses componentes envolvem, basicamente, sua história e condições de vida pessoais e profissionais; seu momento e a rede de apoio com que podem contar; e suas concepções, particularmente sobre o papel da mulher, sobre as necessidades infantis e a creche como alternativa para a educação da criança pequena. Outro fator importante são as características físicas e psicológicas de cada sujeito envolvido. Dentre os componentes da criança, destacam-se sua saúde física e psicológica, seu nível de desenvolvimento, sua história pessoal e, particularmente, sua capacidade de estabelecer e manter relações afetivas e lidar com modificações nas relações preestabelecidas.

\section{DISCUSSÃO}

Concluindo, podemos afirmar que nossa proposta tem como ponto de partida uma perspectiva dialética de natureza fundamentalmente semiótica, o que nos leva a afirmar que o conjunto de fatores físicos, sociais, ideológicos e simbólicos relacionados ao processo de inserção na creche deve ser interpretado como uma rede de significações.

Essa rede, por sua vez, constitui um meio, o qual a cada momento e em cada situação captura/recorta o fluxo de comportamentos do sujeito, tornando-os significativos naquele contexto. Por outro lado, cada sujeito, ao agir, está também recortando e interpretando de forma pessoal o contexto, o fluxo de eventos e os comportamentos de seus 
interlocutores, a partir de sua própria rede de significações. Esses recortes são fundamentalmente definidos pelo papel, posição ou perspectiva assumida por/atribuída ao sujeito, nas ações e interações que ocorrem naquele momento. Seu parceiro ou interlocutor, por intermédio de suas ações, pode lançar um recorte ou interpretação diversa, confrontando e negociando novos significados que, por sua vez, irão reestruturar o contexto e a malha de significações de cada sujeito e de cada díade. Dessa forma, os sujeitos coordenam suas ações e interações por meio dos papéis e contrapapéis que assumem na situação e pela negociação constante dos significados atribuídos ou inovados na situação (Amorim, 1997).

Dessa forma, a probabilidade de os recortes ou interpretações de dois ou mais sujeitos em interação coincidirem é praticamente nula, visto que nunca podem assumir exatamente o mesmo papel, além de trazerem consigo componentes individuais diversos, dentre os quais incluem-se os próprios desejos. Isso, obviamente, leva a desencontros e conflitos que poderão ser, ou não, superados pelas negociações e pelos acordos. Por vezes, levam a situações de maior impasse, as quais exigem, mais do que a superação de um conflito, a ruptura com concepções pré-formadas de papéis ou posições comumente assumidas e construídas ao longo da história de vida do sujeito.

É necessário, ainda, considerar o aspecto da incompletude do processo de significação que ocorre por meio das e nas interações. Nesse sentido, partimos do pressuposto, já elaborado teoricamente por Ciampa (1987), de que nunca o sujeito se apresenta na sua totalidade, qualquer que seja o papel assumido. Além disso, um significado nunca se completa pelo fato mesmo de que ele é construído a partir de diferentes perspectivas. Elas atuam em um movimento no qual, sucessiva e continuamente, umas emergem como figura e outras ficam de fundo (background), em um movimento de contínua mudança, no qual a própria rede de significações sofre contínuas transformações.

Os exemplos citados anteriormente ilustram essas características inerentes às interações e ao processo de significação da experiência vivida, qual seja, sua natureza dinâmica, invariavelmente conflitante, fragmentada e contraditória.

Assim, ao levar seu bebê pela primeira vez à creche, a mãe é invadida/capturada por toda uma malha de significações construída no passado e evocada por elementos presentes, sejam eles internos/pessoais ou externos, físicos ou sociais: emoções, gestos, o novo contexto com salas, objetos, pessoas adultas e crianças novas, a aparência, ação ou fala da educadora, o choro ou sorriso do filho. Essa malha complexa toma a forma de um discurso que a coloca em certa posição, lugar ou papel, estruturando de determinada forma o fluxo de seus comportamentos, ao mesmo tempo em que a faz recortar e interpretar de certa maneira o contexto e as ações dos outros, inclusive do próprio filho. Nesse processo, a educadora, a mãe e o bebê vão se constituindo como sujeitos e transformando continuamente a rede de significações pessoal e coletiva.

Alguns significados, associados a representações e valores sociais mais amplos, são mais persistentes, difíceis de mudar, exigindo por vezes verdadeiras rupturas em relação a 
modelos antigos de pensamento e de afeto. Este é o caso, muitas vezes, da experiência vivida pela mãe ao deixar o seu bebê na creche, aos cuidados de uma pessoa e em um ambiente inicialmente estranhos.

Conforme o momento, o contexto e os personagens, certo conjunto de fatores adquire maior relevo na emergência de novos significados. Assim, uma boa organização do berçário, em termos de espaço, objetos, rotinas, favorecendo as interações de adultos e crianças, em um ambiente afetivo e acolhedor, evoca na mãe uma sensação boa e possivelmente traz à tona boas percepções com respeito a deixar seu filho na creche. $\bigcirc$ mesmo pode ocorrer quando ela coloca seu filho no chão e o vê olhar com interesse para um bebê ao lado, esticando-Ihe a mão em sua direção, sorrindo-Ihe e vocalizando. Nesse momento, a mãe pode sentir-se capturada por uma emoção positiva, a qual a torna mais alerta para elementos positivos da creche.

No caso de a mãe ter saído de casa em conflito, ouvindo o discurso de sua própria mãe (avó da criança) dizendo-lhe que "mãe que é mãe não deixa seu filho em creche" (Rosemberg, 1982), e, ao chegar na creche para pegar o bebê, encontra-o chorando e com febre, destacam-se alguns elementos mais negativos de sua rede de significações, capturando-a em um papel/ugar de mãe descuidada, má. Esse discurso pode ser modificado mediante uma conversa com a educadora, um gesto de apoio do marido, ou agravado com uma crítica da sogra ou do pediatra.

Compreendemos, assim, que os vários aspectos da matriz socioistórica, que capturam a mãe, a criança e a educadora em processo de integração na creche, não estão fora delas e do meio que as cerca. Estão, sim, presentes nos próprios gestos e palavras. Estão, portanto, impregnados nos sujeitos com seus componentes individuais, nos campos de interação e nos cenários, pois todos estão imersos no mundo da linguagem em seu sentido mais amplo, semiótico.

Por sua vez, os sujeitos (Mãe, Criança e Educadora), embora imersos nesse universo simbólico, talvez não estejam tão completamente submetidos a ele, já que a própria natureza biológica do animal humano, evoluída filogeneticamente, impõe limites a essa capturação. No recém-nascido, o comportamento é fruto de uma interação de certas predisposições desenvolvidas pela espécie com os repertórios disponíveis naquela cultura. No entanto, a criança, em seus primeiros dois anos de vida, tem seu desenvolvimento mediado de maneira mais concreta pelo outro, pela pessoa com quem estabelece um maior vínculo afetivo e com quem se encontra, até certo ponto, fundida, assujeitada. Assim, nas entrevistas que gravamos com as educadoras, ouve-se com freqüência a observação de que a facilidade ou dificuldade de que se reveste o processo de inserção de um bebê depende, fundamentalmente, da maneira como a mãe (ou pessoa de maior investimento afetivo com o bebê) interpreta e reage ao ingresso do filho na creche, do relacionamento que estabelece com a educadora de seu filho e com a creche em geral.

Como pessoa capaz de desdobramento, de reflexão sobre si própria e sobre os 
outros e o mundo (e nisto, diferente do bebê), a mãe pode ter momentos de diferenciação desse "assujeitamento", na busca da própria identidade. À medida que a criança torna-se capaz de desdobramento, de espelhamento e de diferenciação, ela também pode opor resistências de caráter diverso à capturação, assumindo um papel mais ativo no processo de interação.

A rede/malha de significações está inscrita no sujeito, construída que é por meio de suas experiências anteriores, podendo estar inscrita no corpo, no gesto, na forma de sentir e agir. Outros elementos têm o suporte de sua inscrição mais fora do sujeito, embora sejam sempre significados por ele e pela cultura. No caso do recém-nascido, cuja experiência de vida é restrita e recente, suas habilidades para exercer seus próprios processo de significação ainda estão muito pouco desenvolvidas. $\bigcirc$ suporte pessoal básico é mais de caráter biológico. Porém, mesmo esse é interpretado na malha de significações da cultura, particularmente pelas ações dos outros que com ele interagem com mais constância, freqüência e maior investimento afetivo. Nessas interações vão se inscrevendo e se construindo novos significados, tanto por/para aquele bebê, como por/para seus parceiros.

Essa rede foi, inicialmente, elaborada para o estudo de situações relacionadas à integração do bebê, de sua família e da educadora, por ocasião do ingresso na creche. Entretanto, desde o início, sugerimos a possibilidade de seu uso na análise de outras situações que envolvessem períodos de crises ou de intensas mudanças (Rossetti-Ferreira, Amorim e Vitória, 1995). Recentemente, esse uso vem se concretizando na análise de outros eventos de desenvolvimento, como na investigação sobre os processos ligados à inserção de crianças portadoras de paralisia cerebral na creche ou pré-escola (Yazlle, 1997).

Além disso, à medida que formulamos a perspectiva acima exposta, buscando compreender a complexa rede de significações que atua sobre o processo de integração da criança e da família à creche, fomos verificando que tal processo nos era útil em nosso trabalho junto a estagiários e profissionais, com o objetivo de realizar diagnósticos institucionais e avaliação da qualidade do atendimento e de interferências em instituições de educação e saúde, assim como em cursos e treinamentos para profissionais dessas áreas. Discutimos, também, que sua estrutura de análise poderia nortear investigações de outros processos biopsicossociais, tais como processos decorrentes de mudanças provocadas por hospitalização/institucionalização, adoção, mudança de escola, de cidade, de emprego ou aposentadoria.

\section{REFERÊNCIAS BIBLIOGRÁFICAS}

AINSWORTH, M. et al. Patterns of attachment. New Jersey: Lawrence Erlbaun Associates, 1978.

AMORIM, K.S. Processo de (re)construção de relações, papéis e concepções a partir da inserção de bebês na creche. Ribeirão Preto, 1997. Dissert. (mestr.) USP. 
ARIÈS, P. História social da criança e da família. Rio de Janeiro: Guanabara Koogan, 1978.

BADINTER, E. Um amor conquistado: o mito do amor materno. Rio de Janeiro: Nova Fronteira, 1985.

BELSKY, J. The Effects of infant day care reconsidered. In: FOX, N., FEIN, G.G. (eds.). Infant day care: the current debate. New Jersey: Norwood, 1990. p. 3-40.

BOWLBY, J. Attachment and loss. New York: Basic Books, 1969. v. I: Attachment.

BRASIL, Leis, Decretos. Lei de Diretrizes e Bases da Educação. Diário Oficial, n. 248, 23 dez. 1996.

BRONFENBRENNER, U. A Ecologia do desenvolvimento humano. São Paulo: Artes Médicas, 1996.

Ecology of the family as a context for human development: research perspectives. Developmental Psychology, v. 22, n. 6, p. 723-42, 1986.

. The Ecology of cognitive development: research models and fugitive findings. In: WORZNIAK, RH., FISHER, K. (eds). Scientific environments. Hinsdale, New Jersey: Erlbowm, 1993. pp. 3-44.

. Toward an experimental ecology of human development. American Psychologist, p. 5|3-31, jul. 1977.

BRONFENBRENNER, U., CROUTER, A.C. The Evolution of environmental models in developmental research. In: MUSSEN, P.H. (ed.). Handbook of child psychology. New York: JohnWiley \& Sons, 1983. v. I, p. 358-413: History, theory, and methods.

CIAMPA, A. C. A Estória do Severino e a história da Severina: um ensaio de psicologia social. São Paulo: Brasiliense, 1987.

CRESAS. Accueillir à la crèche, à l'école. Paris: INRP; L'Harmattan, I99I.

DURHAM, E. Família e reprodução humana. In: DURHAM, E. et al. Perspectivas antropológicas da mulher 3. Rio de Janeiro: Zahar, 1983.

FIORANI, MUSATTI, T. L'Inserimento del bambino al nido e il processo di socializzazione tra coetanei. In: MUSATTI, T., MANTOVANI, S. (eds.). Stare insieme al nido: relazioni sociali e interventi educativi. Juvenilia, 1986.

FOX, N., FEIN, G. (eds.) Infant day care: the current debate. New Jersey: Norwood, 1990.

KUHLMANN Jr., M. Infância e educação infantil: uma abordagem histórica. Porto Alegre: Mediação, 1998. 
MANTOVANI, S., TERZI, N. L'inserimento. In: BONDOLI, A., MANTOVANI, S. (eds.) Manuale critico dell' asilo nido. Milano: Franco Angeli, 1987.

NICHD. The Effects of infant child care on infant-mother attachment security: results of the NICHD study of early child care. Child Development, v. 68, n. 5, p. 860-79, out. 1997.

OLIVEIRA, Z. M. R. Jogo de papéis: uma perspectiva para análise do desenvolvimento humano. São Paulo, 1988. Tese (Dout.)

. Práticas discursivas nas interações de crianças pequenas. Algumas questões metodológicas e conceituais. 1995. (Comunicação apresentada no Simpósio Interação Criança-Criança e os Estudos de Comunicação, realizado na XXV Reunião Anual de Psicologia)

OLIVEIRA, Z. M. R., ROSSETTI-FERREIRA, M. C. Coordination of roles: a theoretical; methodological perspective for studying human interactions. In: MERCER, N., COLL, C. (eds.). Teaching, learning and interaction. Madrid: Ed. P/ del Rio, 1994, v. 3, p. 217-21: Explorations in socio-cultural studies.

. V Valor da interação criança-criança em creches no desenvolvimento infantil. Cadernos de Pesquisa, n. 87, p. 62-70, nov. 1993.

. Propostas para o atendimento em creches no Município de São Paulo: histórico de uma realidade. Cadernos de Pesquisa, n. 56, p.39-65, fev. 1986.

PINO, A. Semiótica e cognição na perspectiva histórica-cultural. Temas em Psicologia: cogniç̧ão e linguagem. n. 2, p. 31-40, 1995.

POSTER, M. Teoria crítica da família. Rio de Janeiro: Zahar, 1979.

PRAMLING, I., LINDALH, M. Entering the world of day-care. Seville, Spain, 1992.

(Paper presented at Vth European Conference on Child Development)

ROCHA, E.A.C. A Pesquisa em educação infantil no Brasil: trajetória recente e perspectiva de consolidação de uma pedagogia. Campinas, 1999. Tese (Dout.)

ROSEMBERG, F. A Criação de filhos pequenos: tendências e ambigüidades contemporâneas In: RIBEIRO, I., RIBEIRO, A.C.T. (org.) Família em processos contemporâneos: inovações culturais na sociedade brasileira. São Paulo: Loyola, 1995. p. 167-90.

. Mãe que é mãe deixa seu filho em creche? Psicologia Atual, p. 38-42, 1982.

ROSSETTI-FERREIRA, M. C. O Apego e as reações da criança à separação da mãe: uma revisão bibliográfica. Cadernos de Pesquisa, n. 48, p. 3-19, fev. 1984.

ROSSETTI-FERREIRA, M. C., AMORIM, K. S., VITÓRIA, T. A Creche enquanto contexto possível de desenvolvimento da criança pequena. Revista Brasileira de Crescimento 
e Desenvolvimento Humano. São Paulo, v. 4, n. 2, p. 35-40, 1994.

. Emergência de novos significados durante o processo de adaptação de bebês à creche. Coletâneas da ANPPEP. Recife, v. I, n. 4, p. I I I-43, set. 1996.

- Integração família e creche: o acolhimento é o princípio de tudo. Estudos em Saúde Mental. Ribeirão Preto, FMRP/USP, p. 107-31, 1997.

. Relevância da investigação sobre desenvolvimento infantil para o aprimoramento da qualidade do atendimento educacional à criança de $0-6$ anos. [Resumo]. In: $3^{\circ} \mathrm{CICLO}$ DE ESTUDOS EM SAÚDE MENTAL CURSO DE PÓS-GRADUAÇÃO EM SAÚDE MENTAL, DA FMRP/USP. Resumo de Simpósio, Ribeirão Preto, 1995. p. 10-3.

ROSSETTI-FERREIRA, M.C. et al (orgs.) Os Fazeres da educação infantil. São Paulo: Cortez, 1998.

SILVEIRA, R. E. S. et al. Oportunidades de contato entre o adulto e as crianças em creches. Revista Brasileira de Estudos Pedagógicos. v. 68, n. I58, p. 130-63, jan./abr. 1987.

SPITZ, R. O Primeiro ano de vida. São Paulo: Martins Fontes, 1979.

SROUFE, I. A. A Developmental perspective on day care. In: FOX, N., FEIN, G.G. (eds.). Infant day care: the current debate. New Jersey: Norwood, 1990. p. 3-40.

VAITSMAN, J. Flexíveis e plurais: identidade, casamento e família em circunstâncias pósmodernas. Rio de Janeiro: Rocco, 1994. p. 13-74.

VALSINER, J. Culture and the development of children's actions. Great Britain: John Wiley \& Sons, 1987.

. Ontogeny of co-construction of culture within socially organized environment settings. In: VALSINER, J. (org.) Child development within culturally structured environments: social co-construction and environmental guidance in development. Norwood, New Jersey: Ablex Publishing Corporation, 1988. p. 283-97.

VIEIRA, L.M.F. Mal necessário: creches no Departamento Nacional da Criança. Cadernos de Pesquisa. n. 67, p. 3-16, nov. 1988.

VITÓRIA, T. Representações de educadoras sobre as mães e familias das crianças da creche. Ribeirão Preto, 1997. Dissert. (mestr.) USP.

VITÓRIA, T., ROSSETTI-FERREIRA, M. C. Processos de adaptação na creche. Cadernos de Pesquisa. n. 86, p. 55-64, ago. 1993.

VYGOTSKY, L. A Formação social da mente. São Paulo: Martins Fontes, 1991.

. Pensamento e linguagem. São Paulo: Martins Fontes, 1993. 
WALLON, H. As Origens do caráter na criança. São Paulo: Nova Alexandria, 1995.

. Os Meios, os grupos e a psicogênese da criança. In: WEREBE, M. J., NADELBRULFERT, J. Henri Wallon. São Paulo: Ática, 1986.

. O Papel do outro na consciência do eu. In: WEREBE, M. J., NADEL-BRULFERT, J. Henri Wallon. São Paulo: Ática, 1986a.

WEREBE, M. J., NADEL-BRULFERT, J. Henri Wallon. São Paulo: Ática, 1986.

YAZLLE, C. H. A Inserção da criança portadora de paralisia cerebral na creche ou préescola: projeto de mestrado. Curso de Pós-Graduação em Saúde Mental, da FMRP/ USP. Ribeirão Preto, 1997. 